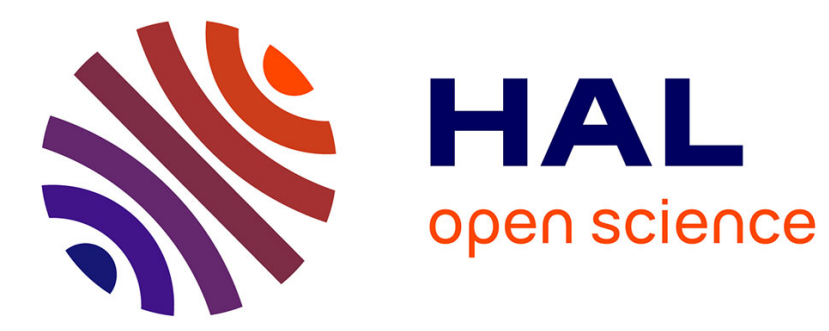

\title{
Russian e-Petitions Portal: Exploring Regional Variance in Use
}

Andrei V. Chugunov, Yury Kabanov, Ksenia Zenchenkova

\section{To cite this version:}

Andrei V. Chugunov, Yury Kabanov, Ksenia Zenchenkova. Russian e-Petitions Portal: Exploring Regional Variance in Use. 8th International Conference on Electronic Participation (ePart), Sep 2016, Guimarães, Portugal. pp.109-122, 10.1007/978-3-319-45074-2_9 . hal-01637222

\section{HAL Id: hal-01637222 \\ https://hal.inria.fr/hal-01637222}

Submitted on 17 Nov 2017

HAL is a multi-disciplinary open access archive for the deposit and dissemination of scientific research documents, whether they are published or not. The documents may come from teaching and research institutions in France or abroad, or from public or private research centers.
L'archive ouverte pluridisciplinaire HAL, est destinée au dépôt et à la diffusion de documents scientifiques de niveau recherche, publiés ou non, émanant des établissements d'enseignement et de recherche français ou étrangers, des laboratoires publics ou privés. 


\title{
Russian e-Petitions Portal: Exploring Regional Variance in Use
}

\author{
Andrei V. Chugunov, ${ }^{1}$ Yury Kabanov, ${ }^{2}$ and Ksenia Zenchenkova ${ }^{1}$ \\ ${ }^{1}$ ITMO University; Saint-Petersburg, Russia; \\ chugunov@egov-center.ru, rabota.ks@mail.ru \\ ${ }^{2}$ National Research University Higher School of Economics, Saint-Petersburg, Russia \\ ykabanov@hse.ru
}

\begin{abstract}
The paper presents the results of research on factors explaining the level of e-petitioning in Russian regions. The main goal is to reveal socioeconomic, technological and institutional problems the regions face, and hence to embed the Russian case into the broad research agenda on online engagement. We concentrate on the federal e-petitions portal - Russian Public Initiative - and use the automated monitoring system to analyse subnational dynamics of online petitions submissions and voting on the aggregate level. The data are used to quantitatively assess the drivers and obstacles for e-participation. Our findings suggest that more active e-petition portal usage in regions is associated with higher socio-economic and technological development, as well as with democratic institutions and better e-government policy. One of the main obstacles to active use of the portal is its institutional design that at the moment provides regions with different opportunities and reinforces participation divides. Future steps, implications for automated monitoring system and some policy recommendations are also discussed.
\end{abstract}

Keywords: E-Petitions, E-Participation, E-Government, Russian Public Initiative, Resource Model, Digital Divide, Institutions, Russian Regions, Automated Monitoring System

\section{Introduction}

Electronic petition systems are considered an important field of inquiry within multidisciplinary e-participation research $[33 ; 26]$. They are usually characterized as "[o]ne of the most prominent and widely used e-democracy tools," [39:453] being "at the forefront of official, fully operational e-democracy activities of governments and parliaments" [24:1]. As more countries are entering the era of e-participation, more opportunities for e-participation students have arisen to test existing theories with empirical data and provide tools for new projects' assessment. Russia is not an exception. In 2012 a campaign pledge of Vladimir Putin to make the Internet work for "di- 
rect referendum democracy" ${ }^{1}$ turned into the Russian Public Initiative portal (www.roi.ru, RPI), a national e-petition portal launched in April 2013. ${ }^{2}$ Despite the fact that few petitions really gain the required number of votes and achieve any practical results, the dynamic of e-petitioning seems more complicated, especially on the regional level. While some regions are relatively active in submitting and voting for petitions, many others remain reluctant to new take advantage of opportunities for participation. Exploring and understanding these disproportions seems quite topical and relevant, both for testing existing theories and better policy-making.

This paper seeks to explore patterns, dynamics and factors of RPI usage variance by Russian regions. Using aggregate level data on RPI petitions and vote counts from the automated monitoring system developed by the eGovernance Center at ITMO University, as well as drawing on existing theories on public engagement, we run quantitative analysis to answer the following research question: What factors can explain the regional differences in e-petitioning (submitting and voting for $e$ petitions)? Although being a part of a broader online-engagement concept, RPI usage seems a valid and measurable proxy to study the Russian case and contribute to the comparative studies of e-petitions initiatives around the globe.

The paper is structured as follows. First we give an overview of the automated monitoring system developed by the eGovernance Center and used for analysing RPI dynamics. Secondly, using this tool, we describe the retrospective and current state of RPI usage. Thirdly we review existing relevant theories on online engagement, epetitioning and e-participation. Finally, we present the results of the analysis to find predictors of e-petitioning in Russia, and define future steps of research.

\section{The Dynamics of E-Petitioning in Russia: Application of Automated Monitoring Approach}

\subsection{Automated Monitoring Tool for RPI Analysis}

Since the opening of the RPI portal in 2013, the eGovernance Center of ITMO University has launched an automated monitoring system for it. ${ }^{3}$ To aggregate data from the portal we use the official Application Programming Interface that provides information about all initiatives and their status: name, description, votes for and against, status, progress and dates of voting. The system allows monitoring dynamics of voting for petitions at a minimum interval of one hour, overall number of votes a day, total voting in the country and regions. It also gathers data of all petitions and has several filters: (1) level of an initiative (federal, regional, and municipal); (2) region; (3) status; (4) categories (topics); (5) votes for and against, etc. In short the system allows for getting any data that is presented in the portal and is valuable for research,

\footnotetext{
Putin, V.V.: Democracy and Quality of Government [in Russian]. Kommersant, 6.02.2012, http://www.kommersant.ru/doc/1866753.

${ }^{2}$ Decree of President of the Russian Federation № 601 On General Directions of Public Government System Development [in Russian], 7.05.2012, http://rg.ru/2012/05/09/gosupravlenie-dok.html.

${ }^{3}$ http://analytics.prior.nw.ru/
} 
in a format ready for analysis. The key research topics it is tuned to address include: 1) positive feedback on the initiative; 2) negative feedback analysis; 3 ) issue salience in certain regions and on the federal level; 4) dynamics of citizens' interest in epetitioning facilities; 5) petition submitting and voting patterns.

Exploring data retrieved from e-participation portals has proven to make valuable contributions to understanding civic engagement, especially when it comes to the analysis of voting behavior and petitions' success and failure. Here we can mention studies of punctuated equilibrium formation in the case of the US portal We the People [7], voting dynamics, e-petition success factors and strategies, and media effects in the UK [12; 40], correlations of social media use and e-participation in Russia [3]. All cases show the advantages of automated monitoring of usage in several respects. First, unlike surveys, it allows work with a larger sample, if not a general population. Secondly, it helps to see detailed dynamics of petitioning and voting behaviour in short time intervals. Thirdly, the monitoring is run online to instantly access the effectiveness of e-participation that could be valuable both for citizens and decisionmakers. Generally it facilitates building and testing hypotheses on citizens' behavior and issues' salience. However there are some limitations. The major one is that data cannot be analysed at the individual level of a petitioner or a voter. Hence to reveal factors of e-participation we need to use aggregate level data.

\subsection{RPI and E-Petitioning in Russia: National and Subnational Dynamics}

This section addresses the dynamics and state-of-the-art in RPI usage that can be revealed via the system described above. As figures show, neither is public interest in RPI stable, nor are citizens overactive in placing their ideas on the portal. In terms of e-petition submission (Fig. 1), the number of initiatives submitted declined rapidly in two months after RPI had been launched, apparently with the loss of media attention to this platform. In August 2015 a rise in activity can be seen, since several salient issues were put into the form of e-petitions, like those connected to the Ukrainian crisis (e.g. to ban destruction of foodstuffs under sanctions). However, at the moment the number of submissions is decreasing and is far from its initial rates. It should be noted that of all the e-petitions about $88 \%$ are federal ones, meaning that citizens tend to influence the national government to establish a federal legal framework rather than to persuade regional or municipal authorities, although these levels seem to be closer to people and easier to get to. The overall voting dynamics (Fig. 2) is to a large extent preconditioned by topics' salience and media attention. The majority of votes are given to popular initiatives, while the rest gain few votes to go any further.

Although the national dynamics is as described, the picture is much more complicated when we consider a regional dimension of RPI usage. Eighty five regions of Russia demonstrate different patterns of submission and voting, as well as a repertoire of topics. About 40 per cent of all petitions are submitted by three regions: Moscow, the Moscow Region and St. Petersburg, while others on average constitute from 0.5 to 2.5 percent. In the case of regional petitions, the abovementioned 3 regions' share is nearly 60 percent. Moscow and the Moscow region are also active on the municipal level, jointly forming 26 percent of e-petitions, while other regions' share varies from 
0 to 5.5 percent (the Nizhegorod Region). It means, first, that against the background of the decline in public interest, we have as many as 85 different dynamics of epetitioning and voting. Secondly, despite the democratic and mobilisation promise of RPI, there are severe disproportions of regional representation, interest to e-petition and opportunities to participate. This problem needs to be addressed in order to determine the factors affecting RPI usage and improve decision-making.

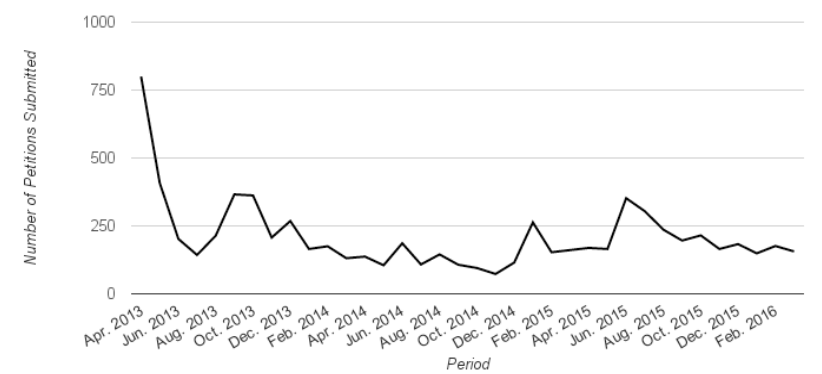

Fig. 1. The number of petitions submitted via RPI portal. (Source: Automated E-Petition Portals Monitoring System by eGovernance Center).

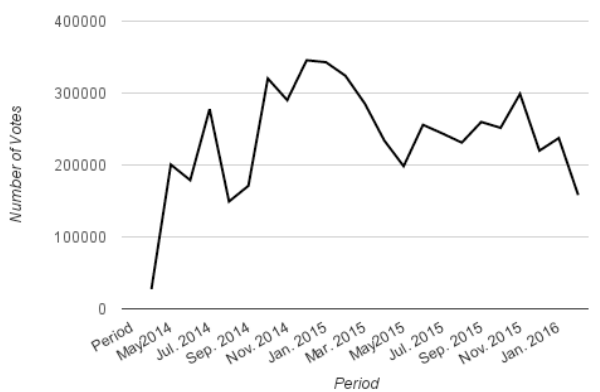

Fig. 2. The number of votes submitted via RPI portal. (Source: Automated E-Petition Portals Monitoring System by eGovernance Center).

\section{Exploring Divides in E-Petitioning: RPI and Russian Regions}

\subsection{Factors of Online Engagement: A Review and the Russian Context}

To approach the question of regional disproportions in e-petitioning we employ several major theoretical perspectives and concentrate on the overlapping ideas that political participation can be shaped by social and economic characteristics, costs and incentives to participate, as well as institutional context. These theories seem quite applicable to the analysis of a broad range of participation practices and tools, both online and offline, and are frequently used by scholars.

Plenty of works emphasise that political participation is practiced by wealthier and more educated citizens, i.e. it is the socio-economic status that matters. But the causal 
mechanisms that unite education, occupation and income are different. A popular concept is the Resource Model, which includes time, money and civic skills as necessary resources to participate, and which appear to be unequally distributed and possessed by people of higher socio-economic status [6]. The rise of the Internet has provoked a debate on whether e-participation will have a mobilisation or reinforcement effect, and whether the digital divide will add to the political one [28]. Empirical literature mainly supports the reinforcement effect, although the structure of divides has been in some respects altered. The fact that those participating and petitioning online are usually men with a higher level of education and income, but usually younger than traditional offline participants, has been found in cases of the United States [4], Germany, Scotland and Norway [23;24;8;32]. The patterns of inequalities are not the same everywhere. For instance, online petitions in Australia, as argued by Sheppard, can help to overcome traditional barriers like income or gender [35]. In the case of Taiwan, the research by Lee et al. shows that e-petitions may mobilise those Internet-users that will not otherwise participate offline [22]. As shown by Vicente and Novo, e-participation may alter gaps surprisingly: while in Spain a gender gap remains, unemployed people are more engaged online due to the lower costs [36]. Despite traditional resources, new Internet-skills are becoming important [27].

Another explanation of the importance of socio-economic status derives from the Theory of Social Capital. It seems that it can also be a meaningful driver of online participation [10], as well as its key components - high level of general and institutional trust [21], although some studies have found an inverse relationship [11]. One more theory is proposed by Inglehart, who argues that modernisation leads to culture and value shifts. Political actions, like petitions, correlate strongly and positively with the rise of postmaterialist values [14: 210-230]. So, be it due to resources, social capital or values, socio-economic characteristics may seriously affect e-petitioning.

Another perspective points out the significance of incentives and motivations, starting from Olson's theory pointing out the necessity of selective incentives or coercion for collective actions [29:2] Although some scholars argue the Internet has altered the way collective actions work [25; 5], Olson's logic remains relevant to epetition portals like RPI, where the activities remain voluntary and anonymous. One way to solve the free-riders problem are collective incentives, generated by social media and deliberation [37]. Another factor is political efficacy, as in the perception of ability to influence politics, or of government responsiveness [9]. Some studies have shown a strong positive relationship between e-participation and political efficacy $[21 ; 19]$, meaning that citizens' intent to participate is based not only on rational calculation, but some personal perceptions of this decision.

Incentives and efficacy always operate within a certain institutional environment and are shaped by public policy. Institutions shape behavior, provide information and incentives, minimize costs and provide collective actions [13]. There are plenty of institutions that affect online participation. We can start from a political regime that may restrict free flows of information and build e-participation for the sake of legitimacy only $[17 ; 18]$. The policy towards e-government and open government also matters [36]. Finally, we should consider the institutional design of e-participation portals as well as the procedures of e-petition processing [38]. Government policy can 
support the mobilisation effect or reinforce existing inequalities, provide incentives or impose costs. Several works successfully combine social and institutional perspectives and reveal that resources, incentives and institutions are interrelated in shaping the level of online engagement $[31 ; 15]$.

What are the implications of the theories to the Russian case? It seems that epetitioning in the country can be explained by all of them. Public opinion polls indicate low interest in traditional petitions: just $4 \%$ of the population in 2013 participated in such an activity, and the level of political efficacy is low. There are no signs that the Internet has changed anything. ${ }^{4}$ While institutional trust is high towards the President $(80 \%)$, the addressees of petitions - the national Parliament, regional and municipal authorities - are trusted much less (40, 38 and 32 per cent accordingly). ${ }^{5}$ It may explain why the lower the level of government is, the fewer petitions are submitted. Public participation in Russia is also highly disproportionate in social and economic terms [34]. The situation is more complicated on the regional level, while regions differ drastically in terms of economic, social and political development.

On the other hand, institutional development of e-government and e-participation in Russia should be considered. The first feature is a variety of subnational political regimes [30] and problems with democracy on the national level, which creates costs to public participation. Russia is not an exception to use e-services as legitimacybuilding tool rather than to encourage online engagement $[1 ; 2]$, but regions demonstrate different approaches to e-government and participation policy [16].

Another feature is the institutional design of RPI. ${ }^{6}$ To submit or vote for a petition one must register via the Unified System of Identification and Authentication (USIA), which is also used to get e-services. Registration requires time-consuming official procedures and hence creates additional costs. To be considered by authorities a federal petition should get 100000 votes in favor, regional or municipal petitions require 5 per cent of the population of the respective regions or municipalities to vote (if the population of a region is over 2 million, 100000 votes are needed). The problem is that although the number of citizens registered in the USIA has increased since 2013, the USIA population varies drastically within the regions. To illustrate how it works we have developed a simple index of the USIA effect for federal and regional petitions (Table 1). We divide the USIA population by a number a votes needed for a petition to be considered by authorities. The higher the index rate, the higher is the probability of petition success at this stage. We see that while citizens of Moscow can cast the necessary votes nearly 28 times it is impossible for Ingushetia to make their petition successful at any level. For the majority of regions about half of users should be mobilised, which is nearly impossible.

One more institutional feature that might hinder collective incentives is the absence of deliberation opportunity on the RPI portal. It is impossible to launch a discussion or information campaign within the portal, unless a petitioner has resources to attract

\footnotetext{
${ }^{4}$ Policy of Non-Interference [in Russian], WCIOM, 10.04.2013, http://wciom.ru/index.php?id=236\&uid=113870

${ }^{5}$ Institutional Trust [in Russian], Levada - Center, 07.10.2015, http://www.levada.ru/old/07-10-2015/institutsionalnoedoverie

${ }^{6}$ Decree of President of the Russian Federation № 183 On Consideration of Public Initiatives Submitted by Citizens of the Russian Federation with the Usage of Internet - Resource "Russian Public Initiative" [in Russian], 4.03.2013, http://base.garant.ru/70326884/\#ixzz44ErQGaGk
} 
media support from the outside. Another problem of the institutional design is that there is a special commission that decides whether a petition goes any further. It has rejected several popular initiatives and insults that such a system lacks legitimacy and trust, and in fact lowers the potential efficacy of participants and increases costs of engagement, despite the promise to change the existing institutions. ${ }^{7}$

Table 1. Indices of the USIA effect on regional and federal e-petitions (Source: Authors calculations based on data by the Russian Ministry of Communication and Russian Statistics Service $)^{8}$

\begin{tabular}{rrrrr}
\hline Region & $\begin{array}{c}\text { Accounts in the } \\
\text { USIA, 2015 }\end{array}$ & $\begin{array}{c}\text { Votes needed } \\
\text { for regional } \\
\text { petition }\end{array}$ & $\begin{array}{c}\text { Index of the re- } \\
\text { gional USIA effect }\end{array}$ & $\begin{array}{c}\text { Index of the federal } \\
\text { USIA effect }\end{array}$ \\
\hline $\begin{array}{r}\text { Moscow } \\
\text { St. Petersburg }\end{array}$ & 2793113 & 100000 & 27.93 & 27.93 \\
Murmansk & 1415858.4 & 100000 & 14.16 & 14.16 \\
$\begin{array}{r}\text { Region } \\
\text { Novgorod }\end{array}$ & 201381.4 & 38300 & 5.26 & 2.01 \\
$\quad$ Region & 62457.1 & 30950 & 2.02 & 0.624 \\
Republic of $\quad \begin{array}{c}\text { of } \\
\text { Ingushetia }\end{array}$ & 19998.4 & 23200 & 0.862 & 0.2 \\
\end{tabular}

In sum, it seems relevant to apply these theories to the Russian case. We hypothesise that higher levels of submission and voting for petitions are associated with: a higher socio-economic performance of the region, in terms of education (1), income (2), Internet use (3) and social well-being (4); more favorable institutional and policy environment, i.e. a more democratic political regime (5), effective e-government (6) and open government (7) policies; institutional design of RPI itself (i.e. lower USIA effect (8), i.e. opportunities for e-petitioning are structured by the rules of registration.

\subsection{Research Design}

To test hypotheses formulated in section 3.1 we use quantitative methods of correlation and regression analysis: while the former helps to see whether any relationship exists, the latter allows understanding causal mechanisms and relative weight of possible e-participation predictors. Our analysis is run on the aggregate level; we analyse the activity of the region in RPI usage rather than a particular individual's attitude. It helps to attract aggregate data on significant characteristics of the region. There are 83 cases in our sample out of 85 Russian regions.

We use two dependent variables: the number of all e-petitions submitted by a region on federal, regional and municipal levels via RPI (RPI_PET) and the number of votes for all petitions cast in a region (RPI_VOTE). The data for variables is retrieved by means of the automated monitoring system described above. In order to solve the

7 The Paranormal on RPI, or Something Must Have Gone Wrong [in Russian], 28.11.2014, https://navalny.com/p/3976/

${ }^{8}$ Indices are calculated as follows: we divide the USIA population by a number a votes needed for petition to be considered by authorities. The higher the index rate, the higher is the probability of petition success at this stage. 
problem of data skewness for analysis we calculate a mean for the period of 2013 2015 and then use natural logarithm of RPI_VOTE and a square root of RPI PET.

To measure independent variables we use data from the Russian Statistics Service, the Ministry of Communication of the Russian Federation, and indices provided by several Russian analytical centers. To overcome some problems with regional statistics we employ a mean of variables taken for the available period within 2007-2015. All variables are divided into two groups. The first one describes the key socioeconomic characteristics of the region: the level of higher education (EDU), natural logarithm of middle income (INCOME), unemployment rate (UNEMP) the share of urban and rural population in the region (URBAN and RURAL), and the Internet use (INTERNET). The second group includes variables that depict institutional and policy features of a certain region: regional political regime in 2012 (REGIME) [30], egovernment policy performance (eGOV), ${ }^{9}$ information openness of regional executive authorities' websites (OPEN) $)^{10}$ and the index of the USIA factor presented in the previous section, for federal and regional e-petitions (USIA_REG and USIA_FED).

\subsection{Analysis, Results and Discussion}

The results of correlation analysis are presented in Table 2. First, we can see a strong and positive correlation between two dependent variables, which means that some regions are overall active in petitioning and voting, others might show no signs of both types of activities. Secondly, the analysis indicates that practically all chosen variables have strong and significant associations.

The socio-economic portrait of a region active in submitting and voting for epetitions looks as follows. First, its citizens tend to be more educated and wealthy, and a region should have less unemployment, which speaks well for resource models and the reinforcement effect of online participation. Secondly, there are clear urban / rural and digital divides among regions that affect their opportunities to participate: more urbanised and Internet-connected regions are more active in RPI use. These factors seem relatively less important for voting (especially income), which might suggest that these two forms of activities require different resources to mobilise.

Institutional settings matters no less than socio-economic characteristics. First, active e-petitioning and voting is positively correlated with a more democratic subnational political regime (REGIME) that apparently allows more in terms of free opinion sharing, media freedom and public policy openness. Secondly, the need for egovernment development, which is also strongly associated with e-petitioning, might be interpreted in several ways. On the one hand, it can be a technical factor: as better e-government facilities increase their importance and convenience for citizens, more people register into the USIA, which in turn means that they can submit or vote for petitions. On the other hand, we can speak about institutional learning, when authorities and citizens tend to trust and become more accustomed to new technologies as a means of political communication. On the contrary, regional government openness

\footnotetext{
${ }^{9}$ Index of Russian Regions E-Readiness (http://eregion.ru/en/ information-inequality-regions), 2007 - 2014

${ }^{10}$ The "Infometer" Research Project (http://www.infometer. org/), 2013 - 2015
} 
appears insignificant and even negative. This confirms that regional authorities are not the key point of reference for citizens. Thirdly, the analysis shows that the institutional design of RPI is crucial, particularly in the case of petition submission

Table 2. Results of Pearson's correlation analysis (Source: Authors' calculations) ${ }^{11}$

\begin{tabular}{rcr}
\hline Region & RPI_PET & RPI_VOTE \\
\hline RPI_PET & 1 & $.607 * *$ \\
RPI_VOTE & $.607 * *$ & 1 \\
EDU & $.692 * *$ & $.426 * *$ \\
INCOME & $.427 * *$ & $.273 *$ \\
UNEMP & $-.383 * *$ & $-.419 * *$ \\
URBAN & $.563 * *$ & $.504 * *$ \\
RURAL & $-.563 * *$ & $-.504 * *$ \\
INTERNET & $.391 * *$ & $.347 * *$ \\
REGIME & $.408 * *$ & $.322^{* *}$ \\
eGOV & $.597 * *$ & $.402 * *$ \\
OPEN & -.158 & -.097 \\
USIA_REG & $.845 * *$ & $.497 * *$ \\
USIA_FED & $.887 * *$ & $.548 * *$
\end{tabular}

Correlation analysis cannot grasp the interrelationship of factors and tells nothing about causality, hence the second step we have taken is a multiple linear regression analysis (ordinary least squares). Our task was to look at how independent variables interact with each other and the dependent one.

The results presented in Table 3 seem confusing: while many factors have shown strong correlation, few remain significant in regression models. Models 1 and 2 take RPI_PET as a dependent variable, and show that e-petitions submission can be explained by level of education and regional e-government performance. These factors lose their significance when controlling for the USIA effect. Models 3 and 4 that use RPI_Vote as a dependent variable show almost the same situation: no factors seem significant except the USIA effect. Of course a further model specification is needed to address the problem of predictors' correlations. However the analysis shows complicated dynamics of e-petitioning in Russian regions, bearing in mind that the USIA effect correlates strongly with all other factors (e.g. ,693** with the level of education, ,532** with e-government development and , $451^{* *}$ with rural population). Both the explanatory force of the USIA effect and its relationship to socio-economic and institutional factors should be interpreted.

First, we assume that inequalities in the USIA registration reinforce socioeconomic disparities and regional institutional context. On the one hand, since the USIA is used primarily to get public services online, we may suppose that people with higher education, income and well-being are more likely to have accounts in the system, because they tend to apply for e-services more often. ${ }^{12}$ Rural areas and low Internet penetration, e.g. in the regions of Caucasus, are also obstacles to successful

11 Correlation is significant at the 0.01 level, * - Correlation is significant at the 0.05 level (2-tailed).

12 For instance, the most popular e-services in Russia are payments of fines for road laws violations, tax payments and applications for travel documents, which seem more topical for people with high income and education in the Russian context. 
diffusion of e-services, while citizens of urbanised and Internet-developed regions, like Moscow and St. Petersburg, have much more motivation and opportunities to use them. On the other hand, regional policies matter as well. Some regions are active in promoting the USIA (Primorsky Krai, Khabarovsky Krai), some show progress in open government (Rostov and Tula regions) and e-government (Tatarstan). The citizens of such regions are hence more informed and motivated to use USIA and eservices in general. The connection of the USIA to RPI may hence divide participation among people in one region, and exacerbate the gap between regions with different levels of socio-economic and policy development. Secondly, taken broadly, the institutional design of RPI presents a range of obstacles for active e-petitioning: time costs for registration via the USIA, absence of deliberation mechanisms and need for extra media attention, as well as high number of initiatives rejected. These factors negatively affect political efficacy and collective action. But again, the importance of such problems may vary across the regions due to differences in subnational political regimes, social capital, government transparency, media freedom, as well as the penetration of alternative online platforms to promote initiatives (e.g. social networks).

Table 3. Results of regression analysis, dependent variables: RPI_PET and RPI_VOTE (Source: Authors' calculations)

\begin{tabular}{ccccc}
\hline Models & \multicolumn{4}{c}{ Std. Beta - Coefficients } \\
\hline Variables & Model 1 & Model 2 & Model 3 & Model 4 \\
\hline EDU & $.435^{* *}$ & .083 & .118 & -.126 \\
INCOME & -.041 & - & - & - \\
UNEMP & -.023 & - & -.120 & -.148 \\
RURAL & -.183 & - & -.251 & -.220 \\
INTERNET & -.135 & - & .020 & -.004 \\
REGIME & .082 & - & .042 & .040 \\
eGOV & $.385^{* *}$ & $.161^{*}$ & .098 & .034 \\
USIA_FED & - & $.745^{* *}$ & - & $.473^{* *}$ \\
Adjusted R-square & .578 & .809 & .188 & .290 \\
Std. Error & 1.77211 & 1.36486 & 1.68089 & 1.57207
\end{tabular}

The findings need to be further examined by more elaborate research models. Overall we conclude that though regional e-petitioning dynamics depends on political, digital and socio-economic divides, as well policy context, the institutional design of RPI strongly and negatively affects this causal relationship.

\section{Conclusion, Recommendations and Future Steps}

Institutionalisation of e-petitioning in Russia in a form of the official governmental portal is a new topic that requires constant attention, as changes affecting online participation patterns are constantly emerging. It is the key rationale to apply automated monitoring systems, which unlike surveys are more precise in fixing the dynamics of submitting and voting for petitions. The data retrieved from the system, as we have shown, can be applicable to a range of research tasks, and helps to understand the complexity of regional variance in use of RPI and test theories on empirical data. 
In this paper we have explored some patterns of regions' inclusion in e-petitioning, and have confirmed the necessity for further research here. On the one hand, the results are well in line with the resource model and previous case studies (Germany, the USA, etc.) showing that e-petitioning replicates existing socio-economic and digital divides, as well as those works that emphasise the importance of favorable institutional environment and effective government policy for incentives, efficacy and collective actions. On the other hand, the institutional design of the petition portal seems to play a meaningful role as an obstacle to equity in regional representation.

To provide more robust results several techniques should be further applied. First, we are planning to use panel data and see the dynamics of change in factors' significance (as the USIA share is changing rapidly at the moment), as well as to use other dependent variables (like the salience of issues in a region) and more elaborate research models. Secondly, new hypotheses should be tested, for example, the role of media effects that can be done via the automated monitoring system as well. Thirdly, the analysis can be well accompanied by case studies to understand details.

The analysis shows the necessity for policy changes as well. First, extra effort should be given to provide equal representation of the regions in the USIA. For the transition period it might be better to change the procedure of petition consideration, and calculate the necessary percent of votes from the share of the USIA population in the region. Secondly, anonymity and lack of deliberation facilities should be addressed, to provide incentives for better collective actions. Thirdly, regarding the opportunities for automated monitoring, the provision of generalised data on social and demographic characteristics (age, gender and residency) could enhance the monitoring process and help to understand the existing divides to properly address them.

\section{References}

1. Åström, J. Karlsson, M., Linde, J., Pirannejad, A. : Understanding the rise of eparticipation in non-democracies: Domestic and international factors. Gov. Inf. Q. 29, 142 - 150 (2012). DOI: 10.1016/j.giq.2011.09.008

2. Bershadskaya, L., Chugunov, A., Trutnev, D.: e-Government in Russia: is or Seems? In: Proceedings of the 6th International Conference on Theory and Practice of Electronic Governance (NY, USA, October 22 - 25, 2012), pp. 79 - 82, ACM New York, New York (2012). DOI: 10.1145/2463728.2463747. 2012.

3. Bershadskaya, L., Chugunov, A., Trutnev, D.: Evaluation of E-Participation in Social Networks: Russian E-Petitions Portal. In.: Janssen, M., Bannister, F., Glassey, O., Scholl, H.J., Tambouris, E., Maria A. Wimmer, M.A., Macintosh, A. (eds.) Innovation and the Public Sector. IFIP EGOV 2014 and ePart 2014, vol. 21., pp. 76-83. IOS, Amsterdam (2014). DOI: 10.3233/978-1-61499-429-9-76

4. Best, S.J., Krueger, B.S.: Analyzing the representativeness of Internet political participation. Political Behavior. 27, 183 - 216 (2005). DOI: 10.1007/s11109-005-3242-y

5. Bimber, B., Flanagin, A. J., Stohl, C.: Reconceptualizing collective action in the contemporary media environment. Communication Theory. 15, 365 - 388 (2005). DOI: 10.1111/j.1468-2885.2005.tb00340.x

6. Brady, H.E., Verba, S., Schlozman, L.: Beyond SES: A Resource Model of Political Participation. 89, $271-294$ (1995). 
7. Dumas, C.L., LaManna, D., Harrison, T. M., Ravi, SS., Kotfila, C., Gervais, N., Hagen, L., Chen, F.: Examining political mobilization of online communities through e-petitioning behavior in We the People. Big Data \& Society. 2, 1 - 20 (2015). DOI: $10.1177 / 2053951715598170$

8. Escher, T., Riehm U.: Petitioning the German Bundestag: Political Equality and the Role of the Internet. Parliamentary Affairs. Advance access published 10 March 2016. DOI: 10.1093/pa/gsw009

9. Finkel, S.E.: Reciprocal Effects of Participation and Political Efficacy: A Panel Analysis. American Journal of Political Science. 29, 891-913 (1985). DOI: 10.2307/2111186

10. Gil de Zúñiga, H., Jung, N., Valenzuela, S.: Social media use for news and individuals' social capital, civic engagement and political participation. Journal of Computer-Mediated Communication. 17, 319 - 336 (2012). DOI: 10.1111/j.1083-6101.2012.01574.x

11. Goldfinch, S., Gauld, R., Herbison, P.: The Participation Divide? Political Participation, Trust in Government, and E-government in Australia and New Zealand. Australian Journal of Public Administration. 68, 333 - 350 (2009). DOI: 10.1111/j.1467-8500.2009.00643.x

12. Hale, S., Margetts, H., Yasseri, T.: Understanding the Dynamics of Internet-based Collective Action using Big Data: Analysing the Growth Rates of Internet-based Petitions. Paper presented at the Annual Conference of the UK Political Studies Association (Cardiff, Wales, 25-27 March, 2013), https://www.psa.ac.uk/sites/default/files/1050 571 0.pdf

13. Hall, P. A., Taylor, R. C. R.: Political science and the three new institutionalisms. Political studies. 44, 936 - 957 (1996). DOI: 10.1111/j.1467-9248.1996.tb00343.x

14. Inglehart, R., Welzel, C.: Modernization, cultural change, and democracy: The human development sequence. Cambridge University Press, New York (2005).

15. Jho, W., Song, K. J. Institutional and technological determinants of civil e-Participation: Solo or duet? Gov. Inf. Q. 32, 488 - 495 (2015).

16. Kabanov, Y., Sungurov, A.: Regional E-governments in Russia: Institutional and Resource Constraints [in Russian]. In: State and Citizens in Electronic Environment: Theories and Technologies of Research, pp. 61 - 72, ITMO University, St. Petersburg, (2015).

17. Karlsson, M.: Carrots and sticks: internet governance in non-democratic regimes. International Journal of Electronic Governance. 6, 179 - 186 (2013). DOI: 10.1504/IJEG.2013.058405

18. Katchanovski, I., La Porte, T.: Cyberdemocracy or Potemkin e-villages? Electronic governments in OECD and post-communist countries. International Journal of Public Administration. 28, 665 - 681 (2005). DOI: 10.1081/PAD-200064228

19. Kenski, K., Stroud, N. J.: Connections between Internet use and political efficacy, knowledge, and participation. Journal of broadcasting \& electronic media. 50, 173 - 192 (2006). DOI: 10.1207/s15506878jobem5002_1

20. Kim, B.J.: Political efficacy, community collective efficacy, trust and extroversion in the information society: Differences between online and offline civic/political activities. Gov. Inf. Q. 32, 43 - 51 (2015). DOI: 10.1016/j.giq.2014.09.006

21. Kim, S., Lee, J.: E-Participation, Transparency, and Trust in Local Government. Public Administration Review. 72, 819 - 828 (2012). DOI: 10.1111/j.1540-6210.2012.02593.x

22. Lee, C., Chen, D., Huang, T. The Interplay Between Digital and Political Divides: The Case of e-Petitioning in Taiwan. Social Science Computer Review. 32, 37 - 55 (2014). DOI: $10.1177 / 0894439313497470$

23. Lindner, R., Riehm, U.: Broadening Participation through E-Petitions? An Empirical Study of Petitions to the German Parliament. Policy \& Internet. 3, 1 - 23 (2011). DOI: $10.2202 / 1944-2866.1083$ 
24. Lindner, R., Riehm, U.: Electronic Petitions and Institutional Modernization. International Parliamentary E-Petition Systems in Comparative Perspective. JeDEM. 1, 1-11 (2009).

25. Lupia, A., Sin, G.: Which public goods are endangered?: How evolving communication technologies affect the logic of collective action. Public Choice. 117, 315 - 331 (2003). DOI: $10.1023 / \mathrm{B}: \mathrm{PUCH} .0000003735 .07840 . \mathrm{c} 7$

26. Medaglia, R.: eParticipation research: Moving characterization forward (2006-2011). Gov. Inf. Q. 29, 346 - 360 (2012). DOI: 10.1016/j.giq.2012.02.010

27. Min, S. J.: From the digital divide to the democratic divide: Internet skills, political interest, and the second-level digital divide in political internet use. J. of Information Technology \& Politics. 7, 22 - 35 (2010). DOI: 10.1080/19331680903109402

28. Norris, P.: Digital divide: Civic engagement, information poverty and the Internet worldwide. Cambridge University Press, New York (2001).

29. Olson, M.: The Logic of Collective Action: Public Goods and the Theory of Groups. Harvard University Press, Cambridge (1971).

30. Petrov, N., Titkov, A.: Rating of Democracy by Moscow Carnegie Center: 10 Years in Service [in Russian]. Moscow, Moscow Carnegie Center (2013).

31. Phang, C. W., Kankanhalli, A., Huang, L.: Drivers of quantity and quality of participation in online policy Deliberation forums. Journal of Management Information Systems. 31, 172 - 212 (2014). DOI: 10.1080/07421222.2014.995549.

32. Saglie. J., Vabo, S.I.: Size and e - Democracy: Online Participation in Norwegian Local Politics. Scandinavian Political Studies. 32, 382 - 401 (2009). DOI: 10.1111/j.14679477.2009.00235.x

33. Sanford, C., Rose, J.: Characterizing eParticipation. Int. J. of Information Management. 27, 406 - 421 (2007). DOI: 10.1016/j.ijinfomgt.2007.08.002

34. Sedova, N. N.: The Formats, Factors, and Social Base of Civic Activism in Today's Russia. Sociological Research. 54, 284 - 306 (2015). DOI: 10.1080/10610154.2015.1123531

35. Sheppard, J.: Online petitions in Australia: Information, opportunity and gender. Australian Journal of Political Science. 50, $480-495$ (2015). DOI: 10.1080/10361146.2015.1049512.

36. Vicente, M. R., Novo, A.: An empirical analysis of e-participation. The role of social networks and e-government over citizens' online engagement. Gov. Inf. Q. 31, $379-387$ (2014). DOI: 10.1016/j.giq.2013.12.006

37. Warren, A. M., Sulaiman, A., Jaafar, N. I.: Social media effects on fostering online civic engagement and building citizen trust and trust in institutions. Gov. Inf. Q. 31, $291-301$ (2014). DOI: 10.1016/j.giq.2013.11.007

38. Wright, S., Street, J.: Democracy, deliberation and design: the case of online discussion forums. New Media \& Society. 9, 849 - 869 (2007). DOI: 10.1177/1461444807081230

39. Wright, S.: Assessing (e-)Democratic Innovations: "Democratic Goods" and Downing Street E-Petitions. J. of Information Technology and Politics. 9, 453 - 470 (2012). DOI: 10.1080/19331681.2012.712820

40. Wright, S.: Populism and Downing Street E-petitions: Connective Action, Hybridity, and the Changing Nature of Organizing. Political Communication. 32, 414-433 (2015). DOI: $10.1080 / 10$ 